\title{
DENISA FEDAKOVA
}

\section{AND ALBERTO VEIRA RAMOS * \\ Job Security Across Europe: Predictors of Subjective \\ Jab Security in Northern, Southern, and Central \\ European Countries \\ Intersections.EEJSP \\ I(5): $100-117$. \\ DDII: 10.17356/ieejsp.v5il.464 \\ http://intersections.tk.mta.hu}

* [dfedak@saske.sk] (Centre of Social and Psychological Sciences, Slovak Academy of Sciences); [aveira@polsoc.uc3m.es] (Universidad Carlos III de Madrid)

\begin{abstract}
According to OECD statistics the unemployment rate in 2011 varied across Europe 10-20 per cent. At that time, European Social Survey Round 5 data was collected which showed that job security was highest in northern country cluster, moderate in southern country cluster, and lowest in the Visegrad country cluster. Our first research question addressed whether general, aggregated social indicators (unemployment and employment rate, and social expenditure) determine perceived job security in the three country clusters. The overall sample was comprised of three southern countries, four Visegrad countries, and four northern countries and consisted of people aged 20-60 who reported to be in paid work and working more than 30 hours a week. The main aim of the current paper was to examine the predictors of job security in the context of all three country clusters. Results indicated that the proposed model of job security predictors showed the best fit for the southern country cluster, explaining over 30 per cent of the variance of perceived job security (background characteristics explained there most of the variance there). Variation in the explanatory power of the job security variable in the northern country cluster was mainly explained by both job and organizational characteristics, while in the Visegrad country cluster it was mainly explained by job characteristics. The paper is a contribution to the discussion about job security in the current period of recession in Europe.
\end{abstract}

Keywords: job security, predictors, European Social Survey Round 5. 


\section{Introduction}

The period between 2007 and 2013 was associated with a significant economic recession worldwide. During this time, declines in economic growth and an increase in unemployment rates were observed throughout Europe. The recession could potentially have had negative consequences on perceptions of work and job security that are important for personal well-being and psychological health. The current paper examines European Social Survey Round 5 data $^{1}$ collected from 2010-2011 in 11 countries with a focus on perceived job security and other variables, including the potential predictors of subjective job security. In this paper we are concerned with the concept of job security, rather than insecurity, and attempt to focus on a positive interpretation of the labour market phenomenon. In order to achieve the aims of the study in a broader context, three country clusters representing three models of market economies across Europe were selected. These included a northern country cluster representing a coordinated market economy, a southern country cluster representing an ambiguous (neither liberal nor coordinated) market economy (Hall and Soskice, 2001), and a central ('Visegrad') country cluster representing a so-called dependent market economy with a dependence on foreign capital (Nölke and Vliegenthart, 2009).

\section{Job security and its predictors}

According to De Witte (2005), job security is defined as the probability that individuals will keep their jobs. Objective job security is indicated by labour market conditions. In this study, however, job security is studied as individual perceptions of job continuity in the future (Sverke and Hellgren, 2002), with a focus on subjective job security. The cognitive and affective forms of job insecurity are not studied in this paper. However, it is obvious that, when considering general job security individual perceptions of the cognitive or affective context cannot be 'excluded' or filtered out. One should be aware that when individuals are asked about perceptions of general job security, they refer either to the probability of their keeping a job (the cognitive context) or about their related feelings and emotions (the affective context).

Despite the clear definitions of job security, little is known about whether the related conceptual frame is the same and even whether its content is comparable. Most employees perceive job security to be essential, particularly as it relates to their current job (Probst and Jiang, 2017). A 2010 survey confirmed that having job security' was rated the most important factor in the working environment, above other factors such as pay, benefits, job-skills training, and career development opportunities (Probst and Jiang, 2017). Reflecting previous findings and outcomes, Richter et al. (2010) have argued that compared to earlier times when organizations were more likely to provide secure jobs, today's employees often need to ensure their own security by staying employable (De Cuyper et al., 2009). Employees have to take greater responsibility for continually developing their human and social capital to be able to find new jobs - on which their careers and economic futures depend. It is

${ }^{1}$ ESS Round 5 data is available online: europeansocialsurvey.org 
worth briefly considering employment security here. While job security refers to the ability to remain in a particular job, employment security refers to the likelihood of remaining in paid employment, albeit through a succession of different jobs. Berglund et al. (2014) have argued that a high degree of employment security, in terms of employability, can compensate for job insecurity.

One potential approach to better understanding the conceptual frame of job security and its perception across countries is to examine job security predictors. Of course, there is a wide range of possible predictors at both the country and individual level. Thus, in this article we deal with three groups of job security predictors: background characteristics, job characteristics, and organizational characteristics, as defined by Ištoňová and Fedáková (2015) and based on a literature review primarily on the topic of job insecurity. The background characteristics that appear to be the most relevant predictors of job (in)security are age, gender, and education, according to papers by Näswall and De Witte (2003), Munoz de Bustilloand and de Pedreza (2010), Ito and Brotheridge (2007), Låstad et al. (2014), and Kirves et al. (2011). Previous experience of unemployment is a significant predictor of perceived job security in the future workplace (De Witte, 1999). Job characteristics, such as type of contract, opportunity for advancement, irreplaceability, employability, and job complexity, have been investigated as predictors of job (in)security in papers by Kirves et al. (2011), Munoz de Bustillo and de Pedreza (2010), McGuinness and Wooden (2009), Chambel and Fontinha (2009), Houston (2011), and Aronsson et al. (2000). Finally, organizational characteristics such as number of employees and the financial situation (e.g. prosperity) of the organization were investigated in relation to job insecurity by Munoz de Bustillo and de Pedreza (2010), Ito and Brotheridge (2007), Nickell et al. (2002), and Kalleberg et al. (2000). In this study we have added organizational meetings and training to this group of characteristics as they represent the attention, care and support an organization provides to its employees, which strengthen perceptions of job security.

\subsection{The country-level context}

In 2011, the document OECD Employment Outlook 2010: Moving beyond the jobs crisis was published. At that time, a common feature of some of the northern, Visegrad, and southern countries was growing youth unemployment (especially in Spain, Slovakia, and Sweden) and a high overall unemployment rate. In 2013, according to OECD statistics, labour market insecurity was highest in Greece, Spain, Italy and Portugal, followed by Slovakia, Poland, and Hungary.

The severity of the problem of insecurity has been documented in numerous published studies that discussed job security/insecurity in northern, southern, and Visegrad countries; however, the former did not examine the aggregate features of job security for country clusters. In relation to Poland, Hungary, the Czech Republic, and Slovakia, papers on job security focused maily on job satisfaction, type of contract, 'flexicurity,' self-rated health, and general predictors, and consequences of job (in)security (OECD, 2017; Maciejewska et al., 2016; Wilczyńska et al., 2015; Mrozowicki et al., 2013; László et al., 2010). In Spain, Greece, and Portugal, papers on job insecurity have tended to associate the phenomenon with youth unemployment and forms of employment such as temporary or flexible work, and to job-related 
attitudes (Sora et al., 2009; De Cuyper et al., 2009b; Becker et al., 2010; Munoz de Bustillo and de Pedreza, 2010). In Denmark, Finland, and Sweden job insecurity has been studied widely in the context of the flexicurity model, public intervention, demographic factors, and social security (Berglund et al., 2014; Richter et al., 2010; De Cuyper et al., 2009a; Anderson and Pontusson, 2007; Hellgren et al., 1999; Kinnunen et al., 1994).

\subsection{Research questions:}

The aim of the present study was to answer the following three research questions:

1. Does the level of reported job security reflect national social indicators, such as unemployment rate, employment rate, and social expenditure? This first research question was formulated to find out (at a descriptive level) whether the perceived job security reported by ESS respondents was affected by objective social indicators in the selected country clusters (using OECD data). We sought to compare the level of the indicators with the level of perceived job security in three country clusters.

2. What are the predictors of job security at the individual/job/organizational level in the three country clusters? The second research question was designed to enable us to describe the different effects of the relevant predictors on job security in the three country clusters using ESS data. With this question we wanted to see if the same variables had a different effect on perceived job security depending on the country cluster.

3. How do the predictors of job security differ in the three country clusters? The third research question was created to help analyse the differences in job security predictors between the three country clusters using ESS data.

\section{Methodology}

Data processing was more confirmatory than exploratory in nature. The aim was to confirm that the selected indicators/variables were predictors, and to reveal differences in significance across the three country clusters. We used ESS Round 5 data (2010) specifically, data from the rotating family, work, and well-being module including respondent characteristics.

\subsection{Sample}

Respondents were classified into three country clusters: a southern European cluster, including Portugal, Greece and Spain $(\mathrm{N}=1806)$; a Visegrad cluster including Czechia, Poland, Hungary and Slovakia $(\mathrm{N}=2818)$; and a northern European cluster including Norway, Denmark, Finland and Sweden $(\mathrm{N}=2627)$. The sample was restricted to those who 1) were 20-60 years old at the time of the interview, 2) reported to having been in paid work during the last seven days, and 3) reported to working more than 30 hours per week. 


\subsection{Measures}

All the items were included in the ESS R5 questionnaire. Some of the original ESS item response scales were reversed (labeled R) so as to reflect the focus on perceived job security rather than job insecurity. All variables and corresponding response scales are presented with the values they had when entered into the statistical analysis.

\section{Perceived job security:}

In the ESS questionnaire the dependent variable is measured by a single item 'My job is secure' on a 4-point response scale ranging from 1 = 'not at all true' to $4=$ 'very true.' For reasons related o statistical analysis we decided to transform this ordinal variable into a binary variable with $0=$ 'not at all true' or 'somewhat true' and $1=$ 'quite true' or 'very true.'

Background characteristics:

Variables that reflect the effect of background characteristics were age, gender $(1$ = 'female'; 0 = 'male'), years of completed full-time education and previous experience of unemployment ( 1 = 'yes'; 0 = 'never unemployed').

\section{Job characteristics:}

The effect of job characteristics on perceived job security was captured by five variables: 1) 'Type of contract' (R), a binary variable where responses were coded 0 if limited, and 1 if unlimited; 2) 'Opportunities for advancement or promotion' (R), an ordinal variable where responses were coded 1 if the respondent disagreed strongly and 5 if the respondent agreed strongly there was a good chance of advancement or promotion; 3) 'Overall employability', an eleven-point scale ranging from 0 if the respondent considered it extremely difficult to find or get a similar or better job to 10 if the respondent thought it would be extremely easy; 4) 'Irreplaceability in current job or position' (R), an eleven-point scale ranging from 0 if the respondent believed that it would be very easy for the employer to find their replacement to 10 if it would be extremely difficult; and 5) 'Job complexity' (R), an eleven-point scale ranging from 0 if the respondent reported it was extremely easy for the employer to monitor their work to 10 if it was extremely difficult.

\section{Organizational characteristics:}

The potential predictors of perceived job security were four characteristics of the organization the respondent worked for: 1) 'Financial difficulties of the organization', with responses ranging from 1 if the respondent reported the organization had been in great financial difficulty over the last three years to 4 if the respondent reported no financial difficulty; 2) 'Hiring employees', with responses ranging from 1 if the respondent felt the organization had significantly reduced employee numbers to 4 if the organization had significantly increased employee numbers; 3) 'On the job training' (R), a binary variable coded 1 if the employer had paid for the respondent's training, and 0 'other' (no training or not paid by the employer); 4) 'Organizational meeting influence' (R), a binary variable coded 1 if the respondent thought employee participation in workplace meetings could influence working conditions and practices, and 0 otherwise.

When analyzing the ESS data estimates, the likelihood of each respondent being part of the sample also had to be considered-which means that the most accurate estimates could be obtained only once the data had been weighted. Population weights were thus applied. The population size weight represents an 
adjustment to ensure that each country is represented in proportion to the size of its population (ESS, 2014).

\section{Results}

First, one general research question concerned whether job security was determined by the social indicators for the selected country cluster (unemployment rate, employment rate, and social expenditure). To answer this question we compared ESS and OECD data collected in 2010-2011. At the descriptive level, the ESS data showed that the level of perceived job security was highest in the northern cluster $\left(\mathbf{M}^{2}=3.1\right)$, moderate in the southern cluster $\left(\mathbf{M}^{2}=2.49\right)$, and lowest in the Visegrad cluster $\left(\mathbf{M}^{2}=2.28\right)$. However, when the country clusters were ranked according to unemployment and employment rates, the southern and Visegrad country clusters ranked in a different order than they did for job security. On social spending ${ }^{3}$, the cluster ranking was in the same order as for job security (i.e. the highest social spending in northern countries, lower in southern countries, and the lowest in Visegrad countries). The northern cluster of countries had a high level of perceived job security, the lowest unemployment rate, the highest employment rate, and the highest level of social spending (see Table 1). Thus, the finding suggests that the examined indicators did not show common pattern in determining job security across country clusters.

Table 1: Job security mean score (ESS data 2010-2011) and social indicators (OECD 2011 data).

\begin{tabular}{lllll}
\hline country cluster & $\begin{array}{l}\text { job security } \\
\text { (mean) }\end{array}$ & unemployment rate & employment rate & social spending \\
\hline northern & 3,1 & $3-8 \%$ & $69-75 \%$ & $21-29 \%$ \\
southern & 2,49 & $10-20 \%$ & $55-63 \%$ & $24-26 \%$ \\
Visegrad & 2,28 & $7-14 \%$ & $55-65 \%$ & $17-22 \%$ \\
\hline
\end{tabular}

To answer the second research question, 'What are the predictors of perceived job security at the individual/job/organizational level in the three country clusters?' we applied a logistic regression analysis with a dichotomous variable for perceived job security. As regards the northern country cluster, the full model explained 17.2 per cent of variance of the job security variable. Previous experience of unemployment was the only background characteristic that was a significant predictor of job security; not being previously unemployed was associated with higher perceived job security. Only two of the five job characteristics - type of contract and job complexity - were significant predictors of perceived job security. More specifically, job security was predicted by having an indefinite contract and a job in which effort was easily monitored and identified. There were three significant predictors of job security in the

\footnotetext{
${ }^{2} \mathrm{M}$ (mean) of perceived job security variable $\mathbf{M y}_{\mathrm{y}}$ job is secure' with a 4-point response scale ranging from 1 not at all true, to 4 very true.

${ }^{3}$ OEDC definition of Social spending: Social expenditure comprises cash benefits, direct in-kind provision of goods and services, and tax breaks with social purposes

(https://data.oecd.org/socialexp/social-spending.htm).
} 
group of organizational characteristics: organizational prosperity (no financial difficulties), a recent increase (or at least no change) in employee numbers, and influence of workplace meetings (see Table 2 in Appendix), indicating that job security was related to prosperous organizations where employee numbers had increased and employee views were taken into account at meetings. In partial models of logistic regression (using the enter method) background characteristics explained 3.3 per cent of variance of the job security variable, job characteristics explained 10.8 per cent, and organizational characteristics explained 9.5 per cent.

We then repeated the procedure for the southern country cluster. The full model explained 30.1 per cent of the variance of the dummy variable accounting for subjective job security. Of the background characteristics, age, education, and previous experience of unemployment were significant predictors of job security. It means that characteristics as being older, having completed more years of education, and not having been unemployed were all increasing job security in southern country cluster. Only two of the five job characteristics - type of contract and opportunities for advancement - were significant predictors of job security. More specifically, job security was predicted by an indefinite contract and opportunities for advancement. There were two significant predictors of job security among the organizational characteristics: organizational prosperity (no financial difficulties), and company training (see Table 3 in Appendix). Surprisingly (and unlike in the northern cluster), in partial models of logistic regression background characteristics explained 19.1 per cent of the variance of job security, job characteristics explained 17.6 per cent, and organizational characteristics 8.1 per cent.

The same analytical procedure was then applied to the Visegrad country cluster. The full model explained 19.7 per cent of the variance of job security. Previous experience of unemployment was the only background characteristic that was a significant predictor of job security, indicating that no (or little) previous unemployment experience was associated with a higher level of perceived job security. All five job characteristics - type of contract, opportunities for advancement, irreplaceability, employability, and job complexity - were confirmed as significant predictors of job securityin Visegrad country cluster. More specifically, job security was predicted by an indefinite contract, job advancement, irreplaceability in current position, employability, and by having a job where effort was easily monitored and recognized. There were three significant predictors of job security in the group of organizational characteristics: organizational prosperity (no financial difficulties), number of employees, and influence of workplace meetings (see Table 4 in Appendix). This indicates that job security was greater at organizations that were prosperous, had an increasing headcount, and took employees views into consideration at workplace meetings. In partial models of logistic regression (using the enter method) background characteristics explained 2.8 per cent of the variance of job security, job characteristics explained 13.5 per cent, and organizational characteristics explained 6.8 per cent.

Lastly, we responded to the third research question, 'How do the predictors of job security differ between the three country clusters?'. Table 5 summarizes the significant and non-significant predictors of job security across the country clusters. First, of the background characteristics, previous experience of unemployment was a significant negative predictor of job security across all three country clusters. In 
southern countries, being older and having completed more years of education was a significant predictor of job security. Gender was not a significant predictor of job security in any of the country clusters. Second, of the job characteristics, having an indefinite contract was a significant predictor of job security across all three country clusters. Opportunities for advancement was confirmed as a significant predictor of job security in the southern and Visegrad country clusters, and job complexity was a significant but negative predictor of job security in the northern and Visegrad country clusters. Irreplaceability and employability were identified as job security predictors in the Visegrad country cluster only. Third, and finally, in terms of organizational characteristics, working for an organization with no financial difficulties significantly predicted job security in all three country clusters. A growing workforce in an organization and influential organizational meetings were significant predictors of job security in the northern and Visegrad country clusters. Company training and company-supported training were significant predictors of perceived job security in the southern country cluster only.

Table 5: Significant predictors of job security in full models for three country clusters

\begin{tabular}{|c|c|c|c|c|}
\hline \multicolumn{2}{|c|}{ Significance of predictors in full model } & $\begin{array}{l}\text { Northern } \\
\text { cluster }\end{array}$ & $\begin{array}{l}\text { Southern } \\
\text { cluster }\end{array}$ & $\begin{array}{c}\text { Visegrad } \\
\text { cluster }\end{array}$ \\
\hline \multirow[b]{4}{*}{ Background characteristics } & gender & - & - & - \\
\hline & age & - & .000 & - \\
\hline & education & - & .000 & - \\
\hline & unemployment experience & .010 & .000 & .018 \\
\hline \multirow{5}{*}{$\begin{array}{l}\text { Job } \\
\text { characteristics }\end{array}$} & contract & .000 & .000 & .039 \\
\hline & advancement & - & .014 & .000 \\
\hline & irreplaceability & - & - & .000 \\
\hline & employability & - & - & .002 \\
\hline & job complexity & .011 & - & .001 \\
\hline \multirow[b]{4}{*}{ Organizational characteristics } & organizational meetings & .006 & - & .000 \\
\hline & organizational education & - & .000 & - \\
\hline & no financial difficulties & .029 & .000 & .006 \\
\hline & hiring employees & .014 & - & .001 \\
\hline
\end{tabular}




\section{Discussion}

This paper sought to confirm which of the main determinants of subjective job security considered in the literature play the most significant role in the three country clusters and thereby contribute to the findings on job security. The simple design of the study does not enable us to explain the phenomenon of perceived job security in detail but it does allow us to make some preliminary points about the determinants of perceived job security. It should be noted that the findings on job security described heere relate to a period of economic recession, and that all the respondents were employed at the time of response.

In general, this study of the predictors of job security has produced several noteworthy findings. Our focus on social indicators as possible determinants of job security at the macro level suggests that a country's level of social spending is a better determinant of perceived job security than its unemployment or employment rates. The proposed model based on background, job, and organizational characteristics showed the best fit with the southern cluster of countries, and the worst fit with the northern cluster of countries. More specifically, differences in the explanatory power of the characteristics between country clusters were observed. In the northern cluster, a large amount of variability in job security was explained by job and organizational characteristics, whereas in the southern country cluster job security was better explained by background and job characteristics. Socio-demographic characteristics also explained a considerable part of the job security variance in southern countries, but not in northern and Visegrad countries. In the Visegrad country cluster, perceived job security was explained to a greater extend by job characteristics. The findings also suggest that job characteristics explained the significant variance in perceived job security across all three country clusters. The model needs to be more robust if it is to explain more about perceived job security. Moreover, an explanatory approach to creating the best model fit for each cluster or country is also required.

Focusing on the predictors separately, age and education were significant predictors of job security in the cluster of southern countries but not in the Visegrad and northern clusters. This finding could be explained by the fact that unemployment in the south affects heavily the young and less educated, which means a large section of the population (older workers) continue to have higher levels of job security than most other people in the Visegrad and northern countries. This finding is in line with what Sapir (2006, 376) has emphasized: '[...] Mediterranean countries (Greece, Italy, Portugal and Spain) concentrate their social spending on old-age pensions and allow for a high segmentation of entitlements and status.'

Gender differences, another sociodemographic issue, were addressed in the question whether being male or female determines subjective perceptions of job security. In our study, gender was not a significant predictor of perceived job security in any country cluster. This finding supports previous research by Marini et al. (1996), but not by Clark (1997), who reported that being male was a predictor of job security. Having no or little experience of unemployment was another background characteristic that was a relevant predictor of perceived job security across all three country clusters during the economic recession.

Another predictor of job security that was significant in all three country clusters was previous experience of unemployment. Interestingly, despite the different 
employment and unemployment rates and even social spending across the country clusters presented in this paper, previous experience of unemployment stood out as a significant predictor of perceived job (in)security in all three country clusters.

Unsurprisingly, having an unlimited contract was a significant predictor of job security in all three country clusters. Näswall and De Witte (2003) found that type of employment (permanent or temporary) played a role in perceptions of job insecurity. Berglund et al. (2014) stated that temporary employees are much more likely to report cognitive job insecurity than permanent employees. Apart from the association between permanent contracts and job security, Scherer (2009) found that fixed-term contracts and the associated job insecurity exacerbated work-life conflict and economic pressure and lessened life satisfaction.

The last predictor that was significant across all the country clusters was the financial stability of the employing organization. According to Sinclair et al. (2010), the fundamental problem with the loss of a job is the risk of losing a main source of income, and the associated financial worries. It may be assumed that if the organization an employee works for appears to be financially stable and has reported no financial difficulties, this prevents financial worries and strengthens feelings of job security.

This paper has some limitations and strengths that should be mentioned. Regarding the limitations first, the measure of job security was a single item which enabled us to obtain an indication of perceived job security among respondents, but did not bring us closer to understanding whether job security is understood in the same way across country clusters. It did not tell us whether the former was purely related to the current job or to financial/employment security as well. Nor could it tell us whether it involved cognitive job security or affective job security. Second, the country cluster approach made for a simple design, but it prevented us from conducting a deeper examination of country-level variation.

Regarding the strengths, the findings of the study are based on representative ESS data and are a relevant contribution to job security research. One aspect is particularly noteworthy. The job security predictors were divided into three groups of characteristics, and the findings clearly indicate that different characteristics are a significant predictor of job security across county clusters. Moreover, testing one universal model on three country clusters enabled us to point out the differences and similarities. Rather than looking at just one context, we examined three different cluster contexts based on different social politics, cultural aspects and backgrounds. This comparative approach has already proved valuable in obtaining a better understanding of the social consequences of the different institutional arrangements that govern labour markets (Soskice, 1990; 1999; Esping Andersen, 1996; 2013). Our findings suggest that in investigating perceived job security, a comparative approach that looks at country clusters that are formed according to similarities regarding certain institutional settings allows for a better interpretation of results obtained at the national level.

To conclude, the findings of this study have specified significant predictors for each country cluster which could be further analyzed in greater detail, including once the related European policies have been designed. Moreover, there is a need for a wider discussion about the social indicators and the background characteristics as part of the psychology of well-being at the individual level, and of welfare sociology at the 
country and societal level. We agree with Baranowski (2017) that subjective welfare develops within a particular context and needs to be considered very carefully otherwise it could lead to more negative than positive consequences. Thus, it is essential that further research on job security and its predictors and consequences is performed within many different contexts and under various conditions.

\section{References}

Anderson, C. J. and Pontusson, J. (2007) Workers, worries and welfare states: Social protection and job insecurity in 15 OECD countries. European Journal of Political Research, 46(2): 211-235.

https://doi.org/10.1111/j.1475-6765.2007.00692.x

Aronsson, G., Gustafsson, K. and Dallner, M. (2000) Sick but yet at work. An empirical study of sickness presenteeism. Journal of Epidemiology \& Community Health, 54(7): 502-509. https://doi.org/10.1136/jech.54.7.502

Baranowski, M. (2017) Welfare Sociology in our times. How social, political, and economic uncertainties shape contemporary societies. Przeglad Socjologiczny, 64(4): 9-26. https://doi.org/10.26485/ps/2017/66.4/1

Becker, S. O., Bentolila, S., Fernandes, A. and Ichino, A. (2010) Youth emancipation and perceived job insecurity of parents and children. Journal of Population Economics, 23(3): 1047-1071. https://doi.org/10.1007/s00148-008-0224-5

Berglund, T., Furåker, B. and Vulkan, P. (2014) Is job insecurity compensated for by employment and income security? Economic and Industrial Democracy, 35(1): 165-184. https://doi.org/10.1177/0143831x12468904

Clark, A. E. (1997) Job satisfaction and gender: why are women so happy at work?. Labour Economics, 4(4): 341-372.

https://doi.org/10.1016/s0927-5371(97)00010-9

Chambel, M. J. and Fontinha, R. (2009) Contingencies of Contingent Employment: Psychological Contract, Job Insecurity and Employability of Contracted Workers. Revista de Psicologíadel Trabajo y de las Organizaciones, 25(3): 207 217. https://doi.org/10.4321/s1576-59622009000300002

De Cuyper, N., Notelaers, G. and De Witte, H. (2009a) Job insecurity and employability in fixed-term contractors, agency workers, and permanent workers: Associations with job satisfaction and affective organizational commitment. Journal of Occupational Health Psychology, 14(2): 193. https://doi.org/10.1037/a0014603

De Cuyper, N., Sora, B., De Witte, H., Caballer, A. and Peiró, J. M. (2009b) Organizations' use of temporary employment and a climate of job insecurity among Belgian and Spanish permanent workers. Economic and Industrial Democracy, 30(4): 564-591. https://doi.org/10.1177/0143831x09336808 
De Witte, H. (2005) Job insecurity: Review of the international literature on definitions, prevalence, antecedents and consequences. SA Journal of Industrial Psychology, 31(4): 1-6. https://doi.org/10.4102/sajip.v31i4.200

De Witte, H. and Näswall, K. (2003) 'Objective' vs 'subjective' job insecurity: Consequences of temporary work for job satisfaction and organizational commitment in four European countries. Economic and industrial democracy, 24(2): 149-188. https://doi.org/10.1177/0143831X03024002002

De Witte, H. (1999) Job insecurity and psychological well-being: Review of the literature and exploration of some unresolved issues. European Journal of Work and Organizational Psychology, 8(2): 155-177. https://doi.org/10.1080/135943299398302

Esping-Andersen, G. (ed.) (1996) Welfare states in transition: National adaptations in global economies. London: Sage.

Esping-Andersen, G. (1990). The three worlds of welfare capitalism. John Wiley \& Sons.

ESS (2014) Weighting Europan Social Survey data. Available at: http://www.europeansocialsurvey.org/docs/methodology/ESS_weighting_data_1 .pdf

ESS (2011). European Social Survey (2011) Round 5 Module on Work, Family and well-being - Question Design Template Draft 3. London: Centre for Comparative Social Surveys, City University London.

Hall, P. A. and D. Soskice (2001) An Introduction to the Varieties of Capitalism, In: P. A. Hall and D. Soskice (eds), Varieties of Capitalism: The Institutional Foundations of Comparative Advantage. Oxford/New York: Oxford University Press: 1-68.

Hellgren, J., Sverke, M. and Isaksson, K. (1999) A Two-dimensional Approach to Job Insecurity: Consequences for Employee Attitudes and Well-being, European Journal of Work and Organizational Psychology, 8(2): 179-195. https://doi.org/10.1080/135943299398311

Houston, D. J. (2011) Implications of occupational locus and focus for public service motivation: Attitudes toward work motives across nations. Public Administration Review, 71(5): 761-771. https://doi.org/10.1111/j.15406210.2011.02415.x

Ištoňová, L. and Fedáková, D. (2015) Predictors and consequences of job insecurity: Comparison of Slovakia and Estonia. Studies of Transition States and Societies, 7(3): 23-37.

Ito, J. K. and Brotheridge, C. M. (2007) Exploring the predictors and consequences of job insecurity's components. Journal of Managerial Psychology, 22(1): 4064. https://doi.org/10.1108/02683940710721938 
Kalleberg, A. L., Reskin, B. F., and Hudson, K. (2000) Bad jobs in America: Standard and nonstandard employment relations and job quality in the United States. American Sociological Rreview, 65(2): 256-278. https://doi.org/10.2307/2657440

Kinnunen, U., Parkatti, T. and Rasku, A. (1994) Occupational well-being among aging teachers in Finland. Scandinavian Journal of Educational Research, 38(3-4), 315-332. https://doi.org/10.1080/0031383940380312

Kirves, K., De Cuyper, N., Kinnunen, U. and Nätti, J. (2011) Perceived job insecurity and perceived employability in relation to temporary and permanent workers' psychological symptoms: a two samples study. International Archives of Occupational and Environmental Health, 84(8): 899-909. https://doi.org/10.1007/s00420-011-0630-y

Låstad, L., Berntson, E., Näswall, K. and Sverke, M. (2014) Do core self-evaluations and coping style influence the perception of job insecurity? European Journal of Work and Organizational Psychology, 23(5): 680-692. https://doi.org/10.1080/1359432x.2013.800678

László, K. D., Pikhart, H., Kopp, M. S., Bobak, M., Pajak, A., Malyutina, S., Salavecz, G. and Marmot, M. (2010) Job insecurity and health: A study of 16 European countries. Social Science \& Medicine, 70(6): 867-874.

https://doi.org/10.1016/j.socscimed.2009.11.022

Maciejewska, M., Mrozowicki, A. and Piasna, A. (2016) The silent and crawling crisis: international competition, labour market reforms and precarious jobs in Poland. In: Myant, M., Theodoropoulou, S., Piasna, A. (eds.) Unemployment, internal devaluation and labour market deregulation in Europe. Brussels: ETUI. 229-254.

Marini, M. M., Fan, P-L., Finley, E., and Beutel, A. M. (1996) Gender and job values. Sociology of Education, 69(1): 49-65. https://doi.org/10.2307/2112723

McGuinness, S. and Wooden, M. (2009) Overskilling, Job Insecurity, and Career Mobility. Industrial Relations, 48(2): 265-286. https://doi.org/10.1111/j.1468232x.2009.00557.x

Mrozowicki, A., Roosalu, T. and Senčar, T. B. (2013) Precarious work in the retail sector in Estonia, Poland and Slovenia: trade union responses in a time of economic crisis. Transfer: European Review of Labour and Research, 19(2): 267-278. https://doi.org/10.1177/1024258913480601

Munoz de Bustillo, R. and de Pedraza, P. (2010) Determinants of job insecurity in five European countries. European Journal of Industrial Relations, 16(1): 5-20. https://doi.org/10.1177/0959680109355306

Näswall, K. and De Witte, H. (2003) Who feels insecure in Europe? Predicting job insecurity from backgound variables. Economic and Industrial Democracy, 24(2): 189-215. https://doi.org/10.1177/0143831x03024002003 
Nickel, S., Jones, P. and Quintini, G. (2002) A picture of job insecurity facing British men. The Economic Journal, 112(476): 1-27. https://doi.org/10.1111/14680297.0j671

Nölke, A., and Vliegenthart, A. (2009) Enlarging the varieties of capitalism: The emergence of dependent market economies in East Central Europe. World Politics, 61(4): 670-702. https://doi.org/10.1017/s0043887109990098

OECD (2017) https://www.oecd.org/statistics/Better-Life-Initiative-country-noteHungary.pdf

OECD (2013) statistics: http://www.oecd.org/statistics/job-quality.htm

OECD Employment outlook (2011) https://www.oecd-ilibrary.org/employment/oecdemployment-outlook-2010_empl_outlook-2010-en

OECD data (2010-2011) https://data.oecd.org/socialexp/social-spending.htm; https://data.oecd.org/emp/employment-rate.htm;

https://data.oecd.org/unemp/unemployment-rate.htm

Probst, T. M. and Jiang, L. (2017) European flexicurity policies: Multilevel effects on employee psychosocial reactions to job insecurity. Safety Science, 100(A), 8390. https://doi.org/10.1016/j.ssci.2017.03.010

Richter, A., Näswall, K., and Sverke, M. (2010) Job insecurity and its relation to work-family conflict: Mediation with a longitudinal data set. Economic and Industrial Democracy, 31(2): 265-280.

https://doi.org/10.1177/0143831x09358370

Sapir, A. (2006). Globalization and the reform of European social models. JCMS: Journal of Common Market Studies, 44(2): 369-390. https://doi.org/10.1111/j.1468-5965.2006.00627.x

Scherer, S. (2009) The social consequences of insecure jobs. Social Indicators Research, 93(3): 527-547. https://doi.org/10.1007/s11205-008-9431-4

Sinclair, R.R., Sears, L.E., Probst, T. and Zajack, M. (2010) A multilevel model of economic stress and employee well-being. In: Houdmont, J. and Leka, S. (eds.) Contemporary Occupational Health Psychology: Global Perspectives on Research and Practice, Vol. 1. Oxford: Wiley-Blackwell, 1-20. https://doi.org/10.1002/9780470661550.ch1

Sora, B., Caballer, A., Peiró, J. M. and De Witte, H. (2009) Job insecurity climate's influence on employees' job attitudes: Evidence from two European countries. European Journal of Work and Organizational Psychology, 18(2): 125-147. https://doi.org/10.1080/13594320802211968

Soskice, D. (1999) Divergent production regimes: coordinated and uncoordinated market economies in the 1980s and 1990s. In: Kitschelt, H., Lange, P., Marks, G. and Stephens, J. D. (eds.) Continuity and change in contemporary capitalism. Cambridge: Cambridge University Press. 101-134.

https://doi.org/10.1017/CBO9781139175050.006 
Soskice, D. (1990) Wage determination: the changing role of institutions in advanced industrialized countries. Oxford Review of Economic Policy, 6(4): 36-61. https://doi.org/10.1093/oxrep/6.4.36

Sverke, M. and Hellgren, J. (2002) The nature of job insecurity: Understanding employment insecurity on the brink of a new millennium. Applied Psychology: An International Review, 51(1): 23-42. https://doi.org/10.1111/1464-0597.0077z

Voßemer, J., et al. (2018) The Effects of Unemployment and Insecure Jobs on WellBeing and Health: The Moderating Role of Labor Market Policies. Social Indicators Research, 138(3): 1229-1257. https:/doi.org/10.1007/s11205-0171697-y

Wilczyńska, A., Batorski, D. and Sellens, J. T. (2016) Employment flexibility and job security as determinants of job satisfaction: the case of Polish knowledge workers. Social Indicators Research, 126(2): 633-656.

https://doi.org/10.1007/s11205-015-0909-6 


\section{APPENDIX}

Table 2: Logistic regression results for northern cluster: partial and full models (Enter method)

\begin{tabular}{|c|c|c|c|c|c|c|c|}
\hline \multicolumn{8}{|c|}{ northern country cluster } \\
\hline \multirow{6}{*}{$\begin{array}{l}\text { Partial model: } \\
\text { background } \\
\text { characteristics }\end{array}$} & gender & -.121 & .177 & .466 & 1 & .495 & .886 \\
\hline & age & -.002 & .009 & .049 & 1 & .824 & .998 \\
\hline & education & .022 & .024 & .824 & 1 & .364 & 1.022 \\
\hline & unemployment experience & -1.089 & .270 & 16.242 & 1 & .000 & .337 \\
\hline & constant & 1.214 & .520 & 5.459 & 1 & .019 & 3.367 \\
\hline & Nagelkerke $\mathbf{R}^{2}=0,033$ & & & & & & \\
\hline \multirow{7}{*}{$\begin{array}{l}\text { Partial model: } \\
\text { job } \\
\text { characteristics }\end{array}$} & contract & 1.407 & .283 & 24.693 & 1 & .000 & .245 \\
\hline & advancement & .264 & .091 & 8.422 & 1 & .004 & 1.303 \\
\hline & irreplaceability & -.042 & .036 & 1.401 & 1 & .237 & .959 \\
\hline & employability & .077 & .036 & 4.734 & 1 & .030 & 1.080 \\
\hline & job complexity & -.110 & .038 & 8.547 & 1 & .003 & .896 \\
\hline & constant & .841 & .418 & 4.052 & 1 & .044 & 2.319 \\
\hline & Nagelkerke $\mathbf{R}^{2}=0,108$ & & & & & & \\
\hline \multirow{20}{*}{$\begin{array}{l}\text { Partial model: } \\
\text { organizational } \\
\text { characteristics }\end{array}$} & organizational meetings & .258 & .075 & 11.910 & 1 & .001 & 1.295 \\
\hline & organizational education & .496 & .191 & 6.726 & 1 & .009 & 1.641 \\
\hline & no financial difficulties & .285 & .097 & 8.612 & 1 & .003 & 1.329 \\
\hline & hiring employees & .224 & .096 & 5.490 & 1 & .019 & 1.251 \\
\hline & constant & -.820 & .324 & 6.384 & 1 & .012 & .441 \\
\hline & Nagelkerke $\mathbf{R}^{2}=0,095$ & & & & & & \\
\hline & gender & -.087 & .198 & .191 & 1 & .662 & .917 \\
\hline & age & -.004 & .010 & .167 & 1 & .683 & .996 \\
\hline & education & .010 & .026 & .146 & 1 & .702 & 1.010 \\
\hline & unemployment experience & -.825 & .319 & 6.687 & 1 & .010 & .438 \\
\hline & contract & 1.199 & .317 & 14.342 & 1 & .000 & .301 \\
\hline & advancement & .149 & .099 & 2.232 & 1 & .135 & 1.160 \\
\hline & irreplaceability & -.032 & .038 & .725 & 1 & .395 & .968 \\
\hline & employability & .067 & .038 & 3.054 & 1 & .081 & 1.069 \\
\hline & job complexity & -.100 & .039 & 6.408 & 1 & .011 & .905 \\
\hline & organizational meetings & .220 & .081 & 7.436 & 1 & .006 & 1.246 \\
\hline & organizational education & .370 & .205 & 3.258 & 1 & .071 & 1.448 \\
\hline & no financial difficulties & .223 & .103 & 4.742 & 1 & .029 & 1.250 \\
\hline & hiring employees & .249 & .101 & 6.097 & 1 & .014 & 1.283 \\
\hline & constant & -.594 & .806 & .542 & 1 & .461 & .552 \\
\hline Full model & Nagelkerke $\mathbf{R}^{2}=0,172$ & & & & & & \\
\hline
\end{tabular}


Table 3: Logistic regression results for southern cluster: partial and full models (Enter method)

\begin{tabular}{|c|c|c|c|c|c|c|c|}
\hline \multicolumn{8}{|c|}{ southern country cluster } \\
\hline \multirow{6}{*}{$\begin{array}{l}\text { Partial model: } \\
\text { background } \\
\text { characteristics }\end{array}$} & gender & -.101 & .112 & .813 & 1 & .367 & .904 \\
\hline & age & .040 & .006 & 44.855 & 1 & .000 & 1.041 \\
\hline & education & .087 & .012 & 51.825 & 1 & .000 & 1.091 \\
\hline & unemployment experience & -1.662 & .160 & 107.372 & 1 & .000 & .190 \\
\hline & constant & -2.148 & .328 & 42.832 & 1 & .000 & .117 \\
\hline & Nagelkerke $\mathbf{R}^{2}=0,191$ & & & & & & \\
\hline \multirow{7}{*}{$\begin{array}{l}\text { Partial model: } \\
\text { job } \\
\text { characteristics }\end{array}$} & contract & 1.943 & .163 & 142.295 & 1 & .000 & .143 \\
\hline & advancement & .217 & .058 & 13.863 & 1 & .000 & 1.242 \\
\hline & irreplaceability & -.042 & .025 & 2.943 & 1 & .086 & .958 \\
\hline & employability & -.021 & .023 & .869 & 1 & .351 & .979 \\
\hline & job complexity & -.014 & .028 & .244 & 1 & .622 & .986 \\
\hline & constant & .482 & .305 & 2.500 & 1 & .114 & 1.619 \\
\hline & Nagelkerke $\mathbf{R}^{2}=0,176$ & & & & & & \\
\hline \multirow{20}{*}{$\begin{array}{l}\text { Partial model: } \\
\text { organizational } \\
\text { characteristics }\end{array}$} & organizational meetings & .130 & .048 & 7.274 & 1 & .007 & 1.139 \\
\hline & organizational education & .762 & .130 & 34.490 & 1 & .000 & 2.143 \\
\hline & no financial difficulties & .255 & .062 & 16.899 & 1 & .000 & 1.291 \\
\hline & hiring employees & .226 & .072 & 9.676 & 1 & .002 & 1.253 \\
\hline & constant & -1.152 & .209 & 30.458 & 1 & .000 & .316 \\
\hline & Nagelkerke $\mathbf{R}^{2}=0,081$ & & & & & & \\
\hline & gender & -.037 & .131 & .081 & 1 & .775 & .963 \\
\hline & age & .041 & .007 & 32.121 & 1 & .000 & 1.041 \\
\hline & education & .061 & .015 & 17.276 & 1 & .000 & 1.063 \\
\hline & unemployment experience & -1.162 & .203 & 32.662 & 1 & .000 & .313 \\
\hline & contract & 1.414 & .201 & 49.493 & 1 & .000 & .243 \\
\hline & advancement & .165 & .067 & 6.072 & 1 & .014 & 1.180 \\
\hline & irreplaceability & -.038 & .028 & 1.771 & 1 & .183 & .963 \\
\hline & employability & -.036 & .026 & 1.951 & 1 & .162 & .964 \\
\hline & job complexity & -.034 & .032 & 1.117 & 1 & .291 & .967 \\
\hline & organizational meetings & .074 & .058 & 1.632 & 1 & .201 & 1.077 \\
\hline & organizational education & .703 & .160 & 19.400 & 1 & .000 & 2.019 \\
\hline & no financial difficulties & .276 & .072 & 14.695 & 1 & .000 & 1.318 \\
\hline & hiring employees & .133 & .084 & 2.502 & 1 & .114 & 1.142 \\
\hline & constant & -2.937 & .602 & 23.806 & 1 & .000 & .053 \\
\hline Full model & Nagelkerke $\mathbf{R}^{2}=0,301$ & & & & & & \\
\hline
\end{tabular}


Table 4: Logistic regression results for Visegrad cluster: partial and full models (Enter method)

\begin{tabular}{|c|c|c|c|c|c|c|c|}
\hline \multicolumn{5}{|c|}{ Visegrad country cluster } & df & Sig. & $\operatorname{Exp}(B)$ \\
\hline \multirow{6}{*}{$\begin{array}{l}\text { Partial model: } \\
\text { background } \\
\text { characteristics }\end{array}$} & gender & -.193 & .097 & 3.931 & 1 & .047 & .824 \\
\hline & age & .002 & .004 & .231 & 1 & .631 & 1.002 \\
\hline & education & .057 & .017 & 11.366 & 1 & .001 & 1.058 \\
\hline & unemployment experience & -.567 & .132 & 18.553 & 1 & .000 & .567 \\
\hline & constant & -.556 & .318 & 3.055 & 1 & .080 & .574 \\
\hline & Nagelkerke $\mathbf{R}^{2}=0,028$ & & & & & & \\
\hline \multirow{7}{*}{$\begin{array}{l}\text { Partial model: } \\
\text { job } \\
\text { characteristics }\end{array}$} & contract & .512 & .127 & 16.241 & 1 & .000 & .599 \\
\hline & advancement & .369 & .055 & 45.059 & 1 & .000 & 1.447 \\
\hline & irreplaceability & .126 & .022 & 33.841 & 1 & .000 & .882 \\
\hline & employability & .086 & .021 & 16.312 & 1 & .000 & 1.089 \\
\hline & job complexity & -.088 & .023 & 13.911 & 1 & .000 & .916 \\
\hline & constant & -.098 & .243 & .162 & 1 & .687 & .907 \\
\hline & Nagelkerke $\mathbf{R}^{2}=0,135$ & & & & & & \\
\hline \multirow{6}{*}{$\begin{array}{l}\text { Partial model: } \\
\text { organizational } \\
\text { characteristics }\end{array}$} & organizational meetings & .217 & .040 & 29.473 & 1 & .000 & 1.242 \\
\hline & organizational education & .039 & .128 & .091 & 1 & .763 & 1.039 \\
\hline & no financial difficulties & .206 & .057 & 13.044 & 1 & .000 & 1.229 \\
\hline & hiring employees & .251 & .063 & 15.857 & 1 & .000 & 1.286 \\
\hline & constant & -1.411 & .214 & 43.644 & 1 & .000 & .244 \\
\hline & Nagelkerke $\mathbf{R}^{2}=0,068$ & & & & & & \\
\hline & gender & -.042 & .123 & .115 & 1 & .735 & .959 \\
\hline & age & .010 & .006 & 2.960 & 1 & .085 & 1.010 \\
\hline & education & .030 & .023 & 1.818 & 1 & .178 & 1.031 \\
\hline & unemployment experience & -.409 & .174 & 5.551 & 1 & .018 & .664 \\
\hline & contract & .335 & .163 & 4.245 & 1 & .039 & .715 \\
\hline & advancement & .372 & .064 & 33.580 & 1 & .000 & 1.451 \\
\hline & no replacement & .115 & .025 & 22.063 & 1 & .000 & .891 \\
\hline & employability & .074 & .024 & 9.238 & 1 & .002 & 1.077 \\
\hline & job complexity & -.085 & .026 & 10.297 & 1 & .001 & .919 \\
\hline & organizational meetings & .211 & .046 & 20.955 & 1 & .000 & 1.235 \\
\hline & organizational education & -.157 & .148 & 1.124 & 1 & .289 & .855 \\
\hline & no financial difficulties & .182 & .066 & 7.638 & 1 & .006 & 1.200 \\
\hline & hiring employees & .238 & .072 & 11.010 & 1 & .001 & 1.268 \\
\hline & constant & -2.259 & .569 & 15.756 & 1 & .000 & .104 \\
\hline Full model & Nagelkerke $\mathbf{R}^{2}=0,197$ & & & & & & \\
\hline
\end{tabular}

